\title{
ОСОБО ОХРАНЯЕМЫЕ ПРИРОДНЫЕ ТЕРРИТОРИИ - ИНСТРУМЕНТ УСТОЙЧИВОГО УПРАВЛЕНИЯ ПРИРОДОПОЛЬЗОВАНИЕМ
}

\author{
Г. Д. Русецкая, Е. А. Дмытерко \\ Байкальский государственный университет, г. Иркутск, Российская Федерация
}

Информация о статье

Дата поступления

27 июля 2017 г.

Дата принятия к печати 20 ноября 2017 г.

Дата онлайн-размещения 27 ноября 2017 г.

\section{Ключевые слова}

Особо охраняемые природные территории; устойчивое управление; природопользование; лесные системы; экологическое равновесие; концепция устойчивого развития

\begin{abstract}
Аннотация
Особая роль в устойчивом управлении природопользованием, в частности лесными системами, отводится созданию и развитию особо охраняемых природных территорий (ООПТ) для сохранения уникальных участков биосферы - суши, акватории с соответствующими слоями атмосфреры и литосфреры, исключенных из традиционного, интенсивного хозяйственного оборота и предназначенных для сохранения экологического равновесия, поддержания среды жизни и здоровья человека. В мире все больше лесных площадей переходит в статус охраняемых, совершенствуются методы управления природопользованием, направленные на достижение целей в рамках концепции устойчивого развития. Особую актуальность сохранение природных территорий приобретает в условиях обострения экологических проблем, связанных с использованием лесосырьевых, минеральных и топливно-энергетических ресурсов. Распределение ООПТ по странам мира определяется географическим положением последних, уровнем их социально-экономического развития, особенностями государственной экологической политики и др. В соответствии с Конвенцией о сохранении биологического разнообразия к 2020 г. планируется охватить особо охраняемыми природными территориями 17 \% суши и 10 \% морской акватории планеты. В России 2017-й объявлен Годом особо охраняемых природных территорий. ООПТ в РФ занимают около 12 \% площади страны, распределение их по регионам крайне неравномерное. Изучение состояния, использования и развития региональных ООПТ выполнено на примере Иркутской области. Доля ООПТ в ее общей площади составляет около 3 \%, что не соответствует статусу региона с учетом значения оз. Байкал - объекта всемирного наследия - и состоянию прибайкальской территории, отличающейся высоким видовым и экосистемным разнообразием. Основные проблемы, характерные для ООПТ Иркутской области, практически идентичны общероссийским. Для избежания риска потери уникальных природных объектов, биоразнообразия, природных систем в целом, нарушения экологического равновесия в большинстве регионов страны необходимо совершенствование законодательной базы для ООПТ, разработка научных основ заповедного дела, соответствующей эколого-экономической политики, реализуемой через создание, использование и развитие особо охраняемых природных территорий.
\end{abstract}

\section{NATURE CONSERVATION AREAS AS A TOOL OF SUSTAINABLE NATURAL RESOURCE MANAGEMENT}

\author{
Genrietta D. Rusetskaya, Elena A. Dmyterko \\ Baikal State University, Irkutsk, Russian Federation
}

\section{Article info}

Received

July 27, 2017

Accepted

Novenber 20, 2017

\section{Abstract}

A particular role in sustainable management of natural resources in general and forest systems in particular is given to the creation and development of nature conservation areas (NCAs) in order to preserve unique areas of the biosphere - land, water areas with correspond- 
Available online

Novenber 27, 2017

\section{Keywords}

Nature conservation areas; sustainable management; natural resource management; forest systems; ecological balance; sustainable development concept ing layers of the atmosphere and lithosphere taken out of the traditional intensive economic turnover and aimed at preserving ecological balance and supporting an environment maintaining life and health of human beings. More and more forest areas around the world are given the status of protected areas and methods of natural resources management aimed at achieving sustainable development goals are being improved. Preservation of nature areas becomes a particularly topical issue considering that environmental problems associated with using forest raw material, mineral and fuel-and-energy resources are aggravated. Distribution of NCAs around the globe depends on the geographical position of a country, its level of social and economic development, peculiarities of the national economic policy, etc. According to the Convention on Biological Diversity natural conservation areas are to take up to $17 \%$ of land and $10 \%$ of water areas of the Earth by 2020. In Russia year 2017 is declared the Year of nature conservation areas. NCAs occupy about $12 \%$ of the total area of the country but they are unequally distributed among the regions. A study of the situation, use and development of regional NCAs is carried out on the example of Irkutsk Oblast. NCAs take up about $3 \%$ of its total area, which does not agree with the status of the region considering the value of Baikal as a World Heritage Site and condition of the territory around it characterized by the great diversity of species and ecosystems. Main problems typical of Irkutsk Oblast NCAs are almost the same as problems countrywide. In order to avoid risks of losing unique natural sites, biodiversity, nature systems in general, upsetting the ecological balance in the majority of regions of Russia, it is necessary to update regulatory framework concerning NCAs, elaborate a scientific basis of the reserve management and studies and develop a suitable ecological and economic policy implemented through the creation, use and development of nature conservation areas.
Концепция устойчивого развития ориентирует на долгосрочные интересы в планировании хозяйственной деятельности и управлении ею, в то время как современная экономическая система нацелена на краткосрочные выгоды.

Обеспеченность природными ресурсами предопределяет развитие общества в целом и отдельных регионов. Особая роль в этом отводится лесным экосистемам, все компоненты которых - древесные, кустарниковые и другие растения, животные, микроорганизмы, а также комплекс почвенных, гидрологических и климатических фракторов - объединены сложными связями и взаимозависимы. Преимущественное отличие ресурсов лесных систем от невозобновляемых - в их способности к самовосстановлению посредством природных циклов и процессов в определенных условиях и по мере их использования. Тем не менее вероятность приближения к пределам использования возобновляемых ресурсов, все больше связанная с ростом населения планеты, управлением лесными системами без учета и глубокого понимания природных законов, баланса экономических выгод и убытков от сохранения, использования и воспроизводства этих систем, ведет к значительным рискам и природным катастрофрам [1].
Лесозаготовительные работы связаны с негативным изменением природной среды и, по существу, представляют собой «добычу» леса. Ресурс эксплуатируется до тех пор, пока не истощится, а затем производство передвигается в другой район. Прежде чем в этих лесах можно будет вновь заготавливать древесину, пройдет много десятилетий. Кроме того, в новых лесах может содержаться меньше ценных пород и живых организмов. В связи с этим важнейшей задачей устойчивого управления лесопользованием является познание законов развития и функционирования лесной системы как целостной системы, ее возможных реакций на возмущения природного и особенно антропогенного характера, определение обусловленных этими законами пределов допустимого воздействия хозяйственной деятельности на системы, использование этих знаний при принятии научно обоснованных решений $[1 ; 2]$.

В последние годы в мире было накоплено достаточно научных доказательств того, что сведение тропических лесов и промышленные рубки малонарушенных лесов (тропических, умеренных и бореальных) - основные причины сокращения биологического разнообразия в мире, снижения обеспечения экосистемных функций лесов, поддержания 
образа жизни и культуры коренных народов и общин, зависящих от леса. Эти события подготовили почву для начала перехода управления лесными системами на принципиально новый уровень - устойчивое лесоуправление ${ }^{1}$ [3]. Особая роль в устойчивом управлении природопользованием, в том числе лесными системами, отводится особо охраняемым природным территориям (ООПТ).

В мире все больше лесных площадей переходит в статус охраняемых и все больше стран совершенствует методы управления лесным хозяйством (исследование продовольственной и сельскохозяйственной организации ООН охватывает 234 страны и территории), что будет способствовать достижению целей в рамках концепции устойчивого развития ${ }^{2}$.

В условиях обострения экологических проблем, в частности связанных с использованием лесосырьевых, минеральных и топливно-энергетических ресурсов, нарушения и деградации природных экосистем на больших территориях возникла необходимость сохранения уникальных участков земной поверхности - особо охраняемых природных территорий. Это участки биосферы (суши, акватории с соответствующими слоями атмосфреры и литосферы), полностью или частично, постоянно или временно исключенные людьми из традиционного, интенсивного хозяйственного оборота и предназначенные для сохранения экологического равновесия, поддержания среды жизни человека и его здоровья, охраны природных ресурсов, ценных естественных и искусственных объектов и явлений, имеющих историческое, хозяйственное или экологическое значение [4; 5].

Согласно Списку охраняемых территорий ООН (2014г.), в мире известно более 209 тыс. охраняемых объектов, занимающих площадь более 39 млн км², что составляет 14,0 \% территории земли и 3,4 \% поверхно-

1 Мир Фэнтези. URL: http://www.wfc2015org. za ; Лесное хозяйство. URL: http://www. fao.org/ forestry/wfc.

${ }^{2}$ Там же. сти Мирового океана ${ }^{3}$. С 1962 г. число охраняемых территорий увеличилось в 23 раза, а их площадь - в 8 раз. Наибольший прирост числа охраняемых территорий наблюдался в период 1992-2014 гг. (рис. 1).

Распределение охраняемых территорий по отдельным странам мира и их доля в земельном фонде определяются многими фракторами, в том числе географическим положением стран, типом их государственного устройства, уровнем социально-экономического развития страны, разнородностью функциональных задач и признаков охраняемых территорий, национальными традициями, особенностями государственной экологической политики и др. [6].

В США первая охраняемая территория Йеллоустонский национальный парк - была создана в 1972 г., и в последующие годы число охраняемых территорий постоянно увеличивалось. В регионах, которые имеют большую историю заповедного дела, таких как Северная и Южная Америка, некоторые районы Африки, преобладают национальные парки.

Основные задачи создания ООПТ, определенные в документах Конгресса по национальным паркам и охраняемым территориям (1992 г.), таковы: защита территорий с нетронутой природой, научно-исследовательская деятельность, поддержание биологической вариабельности, сохранение равновесия в экологической системе, защита уникальных природных объектов культуры, содействие службам по защите природы, развитие рекреации и туризма, экологическое просвещение, сбережение объектов культуры и методов обработки земель.

В соответствии с классификацией Международного союза охраны природы выделено шесть категорий ООПТ, характеризующихся различными условиями осуществления природоохранной и иной деятельности (табл. 1). Доля особо ценных ООПТ (категории la, lb, II) в площади стран мира составляет от 1 до $9 \%$ (в России - 2 \%) [7].

${ }^{3}$ International Union for Conservation of Nature. URL: http: / / www.iucn.org.

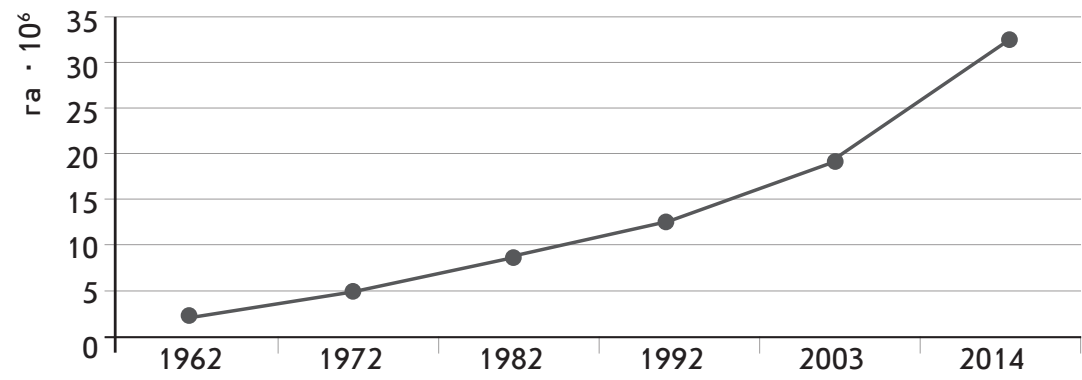

Рис. 1. Динамика площади охраняемых территорий в мире 
Категории ООПт

Таблица 1

\begin{tabular}{|c|l|l|}
\hline Категория & \multicolumn{1}{|l|}{ Тип охраняемых территорий } & \multicolumn{1}{|c|}{ Целевая функция } \\
\hline la & $\begin{array}{l}\text { Особо (строго) охраняемый } \\
\text { природный резерват }\end{array}$ & $\begin{array}{l}\text { Охрана уникальных экосистем; мониторинг окружающей } \\
\text { среды; научные исследования }\end{array}$ \\
\hline Ib & Участок дикой природы & Защита природных характеристик территории (акватории) \\
\hline II & Национальный парк & $\begin{array}{l}\text { Сохранение целостности экосистем; научные исследования; } \\
\text { просветительская, духовная } \\
\text { и рекреационная деятельность }\end{array}$ \\
\hline III & Памятник природы & $\begin{array}{l}\text { Сохранение специфических природных объектов } \\
\text { и факторов }\end{array}$ \\
\hline IV & $\begin{array}{l}\text { Территория с регулированием } \\
\text { среды обитания/видового } \\
\text { состава фрлоры и фауны }\end{array}$ & $\begin{array}{l}\text { Проведение мероприятий по сохранению } \\
\text { и воспроизводству среды обитания } \\
\text { и (или) специфических биологических видов }\end{array}$ \\
\hline V & $\begin{array}{l}\text { Охраняемые наземные и } \\
\text { морские ландшафты }\end{array}$ & $\begin{array}{l}\text { Охрана наземных и морских ландшастов; ведение различных } \\
\text { видов экономической деятельности }\end{array}$ \\
\hline VI & $\begin{array}{l}\text { Территория устойчивого } \\
\text { природопользования }\end{array}$ & $\begin{array}{l}\text { Долговременная защита и поддержание биологического } \\
\text { разнообразия; производство естественных продуктов и услуг }\end{array}$ \\
\hline
\end{tabular}

Программные документы, подготовленные и принятые в рамках реализации международной Конвенции о сохранении биологического разнообразия (1992 г.), ставят целью к 2020 г. охватить особо охраняемыми природными территориями $17 \%$ суши и $10 \%$ морской акватории планеты.

В России заповедное дело начинало развиваться, по сути, с конца XIX в., когда был принят Лесной устав [8]. В 1916 г. был организован первый государственный заповедник - Баргузинский, к 1935 г. было уже 50 заповедников, а к 1951 г. (в СССР) 128 общей площадью 12 млн га. Состояние и развитие охраняемых территорий постоянно претерпевало успехи и провалы.

Заповедному делу России предстояло пережить два глубоких кризиса. С самого начала работы по созданию сети заповедников предпринимались попытки подчинить их деятельность сугубо практическим целям - акклиматизации и разведению хозяйственно ценных животных. В 1951 г. значительная часть заповедников была закрыта, площадь остальных сильно уменьшена. Оставшимся заповедникам предписывалось делать основной упор не на научные исследования и сохранение нетронутой природы, а на практический вклад в «развитие народно-хозяйственного комплекса». К 1953 г. в СССР осталось всего 39 заповедников, и только в начале 1960-х гг. сеть заповедников стала восстанавливаться, их число достигло 85, а площадь превысила 6 млн га. Тем не менее в 1961 г. вновь закрыто 16 заповедников, в большинстве лесных, и на их территориях начались активные лесозаготовки. На основании Положения о государственных заповедниках РСФСР 1962 г. заповедникам вернули статус научно-исследовательских и природоохранных учреждений. В 1990 г. была принята Программа создания общесоюзной системы особо охраняемых природных территорий, после чего сеть заповедников стала расширяться и они начали принимать участие в международных экологических программах. Ряд заповедников был преобразован в биосферные и включен в международные программы исследования взаимодействия человека и природы.

В настоящее время в России последовательно реализуется государственная политика развития ООПТ на принципах устойчивого развития, 2017-й объявлен Годом особо охраняемых природных территорий с проведением программных мероприятий по развитию науки и популяризации знаний, природоохранных акций и др. ${ }^{4}$

Нормативное закрепление понятия «особо охраняемые природные территории» осуществлено в Федеральном законе "Об особо охраняемых природных территориях» от 14 марта 1995 г. № 33-Ф3 (с изменениями и дополнениями от 3 июля, 28 декабря 2016 г.). Из него следует, что ООПТ - это участки земли, водной поверхности и воздушного пространства над ними, где располагаются природные комплексы и объекты, которые имеют особое природоохранное, научное, культурное, эстетическое, рекреационное и оздоровительное значение ${ }^{5}$.

${ }^{4}$ Об утверждении плана основных мероприятий по проведению в 2017 г. в Российской Федерации Года особо охраняемых природных территорий [Электронный ресурс] : распоряжение Правительства РФ от 26 дек. 2015 г. № 2720-р // СПС «КонсультантПлюс».

${ }^{5}$ Об особо охраняемых природных территориях [Электронный ресурс] : федер. закон РФ от 14 марта 1995 г. № 33-Ф3 (ред. от 28 дек. 2016 г.) // Там же. 
Общие признаки категорий ООПТ (ст. 2, п. 1 закона) должны учитываться при принятии решений о создании таких территорий: значение соответствующей территории для сохранения биологического разнообразия, в том числе редких, находящихся под угрозой исчезновения и ценных в хозяйственном и научном отношении объектов растительного и животного мира и среды их обитания, наличие в границах соответствующей территории участков природных и культурных ландшафтов, представляющих собой особую эстетическую, научную и культурную ценность, геологических, минералогических и палеонтологических объектов.

В настоящее время в России насчитывается более 13 тыс. ООПТ федерального, регионального и местного значения, занимающих около 12 \% площади страны.

Распределение и плотность ООПТ по субъектам страны значительно различаются. Так, площадь ООПТ в Севастополе составляет 30,4 \%, в Кабардино-Балкарской Республике - 26,6\%, а, например, в Чукотском автономном округе $-4,8 \%$, Томской области - 3,9\%, Иркутской области - 3,4\%, Курской области - 0,2\%.

Как показывает мировой опыт, общая площадь особо охраняемых природных объектов должна составлять не менее $20 \%$ общей площади России.

В целом доля площади в субъектах Федерации, отведенной под ООПТ, формировалась на протяжении многих лет и определялась не только географическим положением и уровнем хозяйственного освоения региона, но и во многом государственной политикой в сфрере территориальной охраны природы, прово-

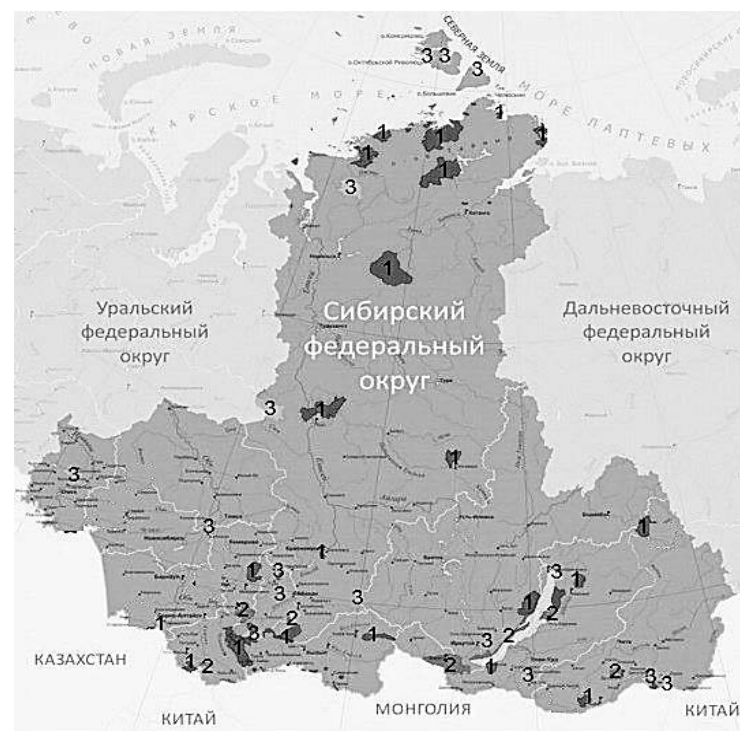

димой руководством конкретных регионов в разные годы и десятилетия (рис. 2). Наиболее ценные природные комплексыи объектыпредставлены в масштабах федеральной системы ООПТ в первую очередь государственными природными заповедниками, национальными парками и федеральными заказниками.

Обширные экосистемы Сибири и Дальнего Востока представляют собой одну из последних возможностей сохранения природных ландшафртов в масштабах, позволяющих сберечь участки настоящей девственной природы и дать экологическим процессам и популяциям диких животных развиваться естественным путем. Лесные комплексы по своему уровню разнообразия и эндемизма превосходят аналогичные комплексы в лесах умеренной зоны любого другого региона мира. Эти леса являются также примером разнообразия человеческих культур, в частности культур коренных жителей Сибири и Дальнего Востока.

Нетронутые острова бореальных лесов и другие леса притундровой зоны представляют большую ценность для мониторинга воздействия глобального изменения климата, поскольку их репродуктивное состояние должно быть индикатором любого устойчивого повышения температуры на высоких широтах 6 .

Изучение состояния, использования и развития региональных особо охраняемых природных территорий выполнено на примере ООПТ Иркутской области, количественные характеристики которых приведены в табл. 2 в сравнении с данными в целом по Российской Федерации.

\footnotetext{
${ }^{6}$ Россия. Лесная политика в переходный период. Вашингтон : Всемир. банк, 1997. 347 с.

ООПТ федерального значения:

$1-21$ государственный природный заповедник

$2-7$ национальных парков

$3-16$ государственных природных заказников федерального значения
}

Доля площади ООПТ от площади субъекта:

Республика Алтай - 25,1 \%

Кемеровская область - 13,7\%

Республика Бурятия - 13,4\%

Республика Хакасия - 12,2\%

Новосибирская область - 8,2 \%

Красноярский край $-7,1 \%$

Остальные субъекты СФО - менее 6 \% 
ООПт России и Иркутской области

\begin{tabular}{|c|c|c|c|c|}
\hline \multirow{2}{*}{ Категория ООПТ } & \multicolumn{2}{|c|}{ Россия } & \multicolumn{2}{|c|}{ Иркутская область } \\
\hline & Количество & Площадь, млн га & Количество & Площадь, тыс. га \\
\hline Государственные природные заповедники & 102 & 34 & 2 & 1246 \\
\hline Национальные парки & 49 & 14 & 1 & 417 \\
\hline Федеральные заказники & 71 & 12 & 2 & 182 \\
\hline Природные парки & 64 & 14 & - & - \\
\hline Региональные заказники & 2300 & 47 & 13 & 775 \\
\hline Памятники природы & 8360 & 3 & 81 & 14 \\
\hline $\begin{array}{l}\text { Иные ООПТ регионального } \\
\text { и местного значения }\end{array}$ & 2360 & 82 & 1 & 0,03 \\
\hline Итого общая площадь ООПт & - & 207 & - & 2634 \\
\hline
\end{tabular}

Общая площадь ООПТ России в составе РФ составляет около $12 \%$, в Иркутской области - 3 \% ее общей площади, что не соответствует статусу региона, особенно с учетом значения оз. Байкал - объекта всемирного наследия ЮНЕСКО - и состояния прибайкальской территории.

Область расположена на юге Восточной Сибири, почти в центре Азиатского материка, на основных транспортных магистралях, соединяющих Европу с дальневосточными районами России и странами Азиатско-Тихоокеанского региона. Площадь территории Иркутской области - 767,9 тыс. км², что составляет 4,6\% территории России. По этому показателю она находится на шестом месте в России и на втором - в СФО.
Бо́льшая часть территории Иркутской области занята землями лесного фоонда - 89,48 \% (69 332,4 тыс. га) от общей площади земельного фонда области, по этому показателю область относится к числу многолесных среди субъектов Российской Федерации. Здесь значительные запасы сосны и кедра. На долю земель ООПТ и объектов приходится 2 \% (1 552,4 тыс. га) от земель лесного фонда (рис. 3). На территории области представлены различные виды ландшафтов: высокогорные, горно-таежные, лесостепные, степные, криоксеропетрофитные степи скалистых побережий.

Схема ООПТ Иркутской области показана на рис. $3^{7}$.

7 О состоянии и об охране окружающей среды Иркутской области в 2016 г. : гос. докл. Иркутск, 2017. 274 с.
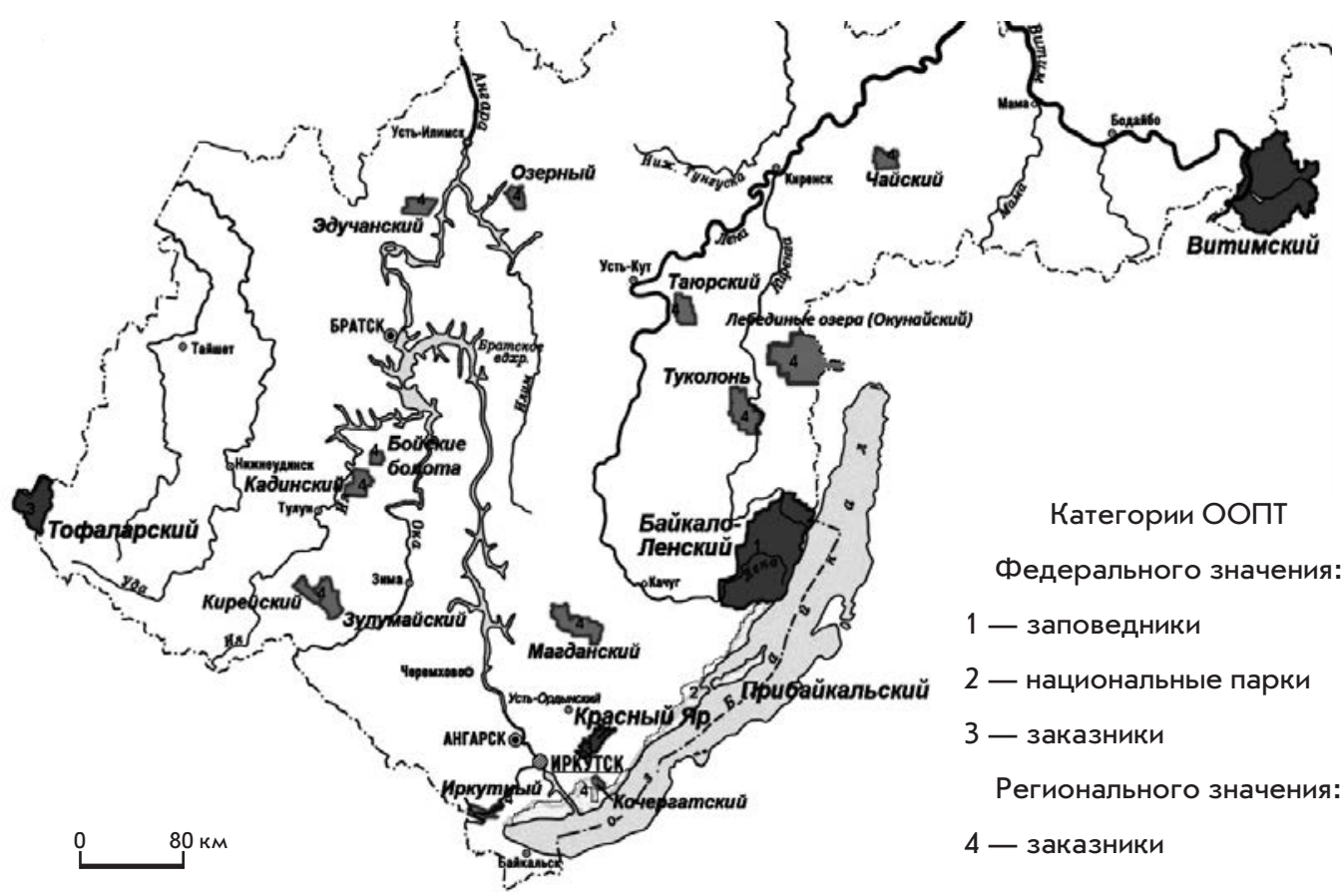

Рис. 3. ООПт в Иркутской области

1 - заповедники

2 - национальные парки

3- заказники

Регионального значения:

4 - заказники 
Область отличается высоким видовым и экосистемным разнообразием. Здесь произрастает свыше 1750 видов растений, из них около 500 являются лекарственными и обладают полезными свойствами. Многие из этих растений в настоящее время занесены в Красную книгу и находятся на грани вымирания. На территории области можно встретить свыше 300 видов птиц, наиболее популярные глухарь, тетерев, рябчик. Уникальные виды птиц - клест, оляпка, кедровка, даурская (бородатая) куропатка и др.

Из 75 видов млекопитающих в таежных районах чаще всего встречаются такие животные, как северный олень, косуля, кабан и лось. Из хищных животных область населяют рысь, росомаха, лисица, волк и соболь. Одним из крупных представителей животного мира области является бурый медведь. Гораздо реже встречается сибирский горный козел. Его численность становится все меньше с каждым годом. Среди более крупных животных Иркутской области можно выделить также зайца-беляка, редкого изюбра, белку, безрогого оленя - кабаргу и снежного барана. Населяют территорию и летяги. Самые редкие обитатели области - нерпа, тюлень. В оз. Байкал обитает голомянка, которая нигде больше не встречается. Всего в регионе насчитывается 65 видов рыб. Крупная рыба озера - осетр, но, кроме нее, еще встречаются таймень и налим. Есть и другие, не менее уникальные представители животного мира. Например, на территории Иркутской области водится кабан, дикая свинья, ласка. Все это уникальное разнообразие требует защиты и бережного отношения.

В Красную книгу Иркутской области занесено 25 видов грибов, 50 видов лишайников, 40 видов мохообразных, 173 вида сосудистых растений, 1 вид пиявок, 1 вид амебовидных, 14 видов ракообразных, 10 видов насекомых, 12 видов рыб, 2 вида рептилий, 2 вида амфибий, 62 вида птиц и 17 видов млекопитающих. В области насчитывается 408 видов представителей животного и растительного мира, которые находятся под угрозой исчезновения.

Среди исчезающих растений - реликтовое растение Сибири ландыш майский, башмачок крупноцветковый (представитель семейства орхидей), аир болотный и представитель плаунов полушник озерный. Полушник озерный - водное травянистое растение, растущее в пределах оз. Байкал на глубине более 4 м на песчаном или песчано-илистом дне озер. Это растение не выдерживает малейшего загрязнения водоемов. Поэтому промышленные отходы, попадающие в озера, осушение болот, питающих озера и фильтрующих их воды, приводят к исчезновению полушника озерного как вида.

Среди исчезающих животных Иркутской области красный волк, снежный барс - ирбис, белохвостый орлан, сибирский осетр, нерпа и эндемик Байкала рыба голомянка.

Вместе с тем на территории области активно развивается промышленность, осваиваются месторождения полезных ископаемых, увеличиваются объемы рубок леса. В этих условиях важнейшей задачей является сохранение уникальной природы, экосистем, животных и растений, поиск путей их рационального освоения в сочетании с научно обоснованным промышленным развитием региона. Необходимо увеличение количества и площади ООПТ в регионе.

Площадь особо охраняемых природных территорий в Иркутской области по отношению к общей площади региона ничтожно мала. Область в настоящее время занимает одно из последних мест в Российской Федерации по площади под ООПТ - 3,4 \%, из которых 2,4 \% приходится на ООПТ фредерального подчинения - два заповедника (Витимский и Байкало-Ленский) и Прибайкальский национальный парк общей площадью 1 550,3 тыс. га (99,9\% от ООПТ Иркутской области). Региональные ООПТ составляют всего около 1 \% территории области. При этом в наиболее нарушенных степных и лесостепных районах региональные ООПТ вообще отсутствуют. Этого крайне недостаточно для сохранения экосистем региона. Для Иркутской области необходимо принять нормативный акт о резервировании территориальных комплексов с целью создания особо охраняемых природных территорий в соответствии с нормативами Федерации, разработать региональную стратегию сохранения биоразнообразия, которая должна хорошо вписываться в государственную стратегию и создаваться при совместном участии всех пользователей лесными и другими природными ресурсами. Проблемы создания, использования и развития ООПТ Иркутской области практически идентичны общероссийским. Для улучшения ситуации нужны изменения прежде всего в правовой основе относительно порядка создания организации и контроля за деятельностью ООПТ.

В настоящее время законодательство выделяет шесть категорий ООПТ, различающихся режимом, целью, уровнем управления. Некоторые из них частично не соответствуют своему официальному статусу, что связано с изменением условий выделения этих территорий за длительную историю их развития 
в России [9]. Так, в начале XX в. для защиты отдельных видов животных создавались заповедники, что в настоящее время более соответствует категории заказников. В задачи многих заповедников включалось развитие рекреации и туризма, такая категория, как национальные парки, в законодательстве Российской Федерации отсутствовала в течение длительного периода. С учетом этих несоответствий в новой редакции федерального закона предусмотрен переход государственных заповедников в национальные природные парки, что необходимо осуществить на практике.

Низкая результативность исполнения Федерального закона «Об особо охраняемых природных территориях" связана также с некоторым несоответствием отдельных его положений и положений гражданского, земельного и лесного законодательства РФ. Одно из противоречий состоит в том, что по закону от 14 марта 1995 г. № 33-Ф3 ООПТ определены как территории и как юридические лица. Например, заповедник - федеральное государственное учреждение, к задачам деятельности которого относится осуществление охраны природных территорий, организация и проведение научных исследований, включая ведение Летописи природы, осуществление экологического мониторинга, экологическое просвещение, участие в государственной экологической экспертизе, содействие в подготовке научных кадров и специалистов в области охраны окружающей природной среды, а это относится к задачам не территорий, а учреждений [10]. Также, согласно определению в законе об ООПТ, «особо охраняемые природные территории - участки земли» ${ }^{8}$, что не в полной мере отражает само понятие.

Многие вопросы ООПТ как учреждений остаются юридически не проработанными. Из-за того что понятия ООПТ как территории и как учреждения не разведены, нормы закона об ООПТ оказываются «недописанными», имеются противоречия между положениями отдельных статей закона об ООПТ.

Для сохранения водных объектов животного и растительного мира и среды их обитания Федеральным законом «О рыболовстве и сохранении водных биологических ресурсов» (от 20 декабря 2004 г. № 166-Ф3) не предусмотрено создания ООПТ, которые признаны в качестве мер охраны природных объектов ст. 58 Федерального закона «Об охране окружающей среды» и предусмо-

${ }^{8}$ Об особо охраняемых природных территориях : федер. закон РФ от 14 марта 1995 г. № 33-Ф3 (ред. от 28 дек. 2016). трены подп. «д» п. 1 ст. 72 Конституции Российской Федерации и законом об ООПТ.

Ситуация с юридической непроработанностью норм Федерального закона «О рыболовстве и сохранении водных биологических ресурсов» приводит к разночтению норм различных отраслей законодательства при регулировании вопросов сохранения водных биоресурсов, путанице при выборе вида особо охраняемой территории и препятствует эффективной реализации норм указанных законодательных актов.

В Кодекс Российской Федерации об административных правонарушениях внесены изменения (апрель 2010 г.), в соответствии с которыми государственные инспекторы по охране территорий государственных природных заповедников и национальных парков лишены права составлять протоколы в охранных зонах заповедников и национальных парков и других ООПТ, находящихся в ведении заповедников и национальных парков. Bce эти нововведения лишили инспекторов возможности контролировать прилегающие к заповедникам и национальным паркам территории, что, в свою очередь, повлекло за собой рост браконьерства и разрушение ценных природных комплексов.

В последние годы органами власти различных уровней было принято большое количество решений, которые привели к разрушению особо охраняемых природных территорий: изменению границ, изъятию территорий, вовлечению в интенсивную хозяйственную деятельность отдельных ООПТ, ослаблению законодательной защиты системы ООПТ в целом, прав должностных лиц, осуществляющих их охрану, ухудшению кадрового состава руководителей системы9. В результате возможности ООПТ в этом отношении значительно ослабли, что связано и с кризисом в научной деятельности и существенной утратой контроля за деятельностью на охраняемых территориях. Для решения природоохранных и экономических проблем необходимо сохранение и развитие заповедного дела, совершенствование методов управления, определение критериев и индикаторов для мониторинга биоразнообразия и общего состояния экосистем. Это требует усилий на стадии разработки политики природопользования, управления практическими средствами ее осуществления, установления пространственно-временных зависимостей между разными видами использования ре-

9 Состояние сети особо охраняемых природных территорий России. Проблемы и пути решения : крат. аналит. обзор / Гринпис России. М., 2012. 37 с. 
сурсов, сравнения затрат и выгод от их эксплуатации и сохранения.

Споры в природоохранном сообществе о том, насколько святы и неприкасаемы для людей должны быть заповедные уголки России, давно стали частью природоохранных дискуссий. Их спектр практически безграничен - от стремления чиновников и правительства получить хоть что-то от этих «бесполезно висящих на бюджете» земель до стремления экологов сохранить эталонные природные комплексы разных регионов в абсолютной неприкосновенности. Здесь и заложен конфликт между «абсолютной заповедностью», еще сохранившейся в некоторых регионах России, и стремлением к прибыли, навязанный стране в начале 1990-х. Сложившиеся конфликтные ситуации «общество - природа» множатся. Чем больше людей приходит на заповедные территории, принося доход бюджету и чиновникам, тем меньше там остается элементов естественной природной среды, ради которой, собственно, вся заповедная система и создавалась.

При этом выход из конфликта существует. У заповедников всегда были и кое-где сохраняются буферные зоны, оборудованные экологические тропы и инорормационные центры, которые позволяют гостям, приносящим деньги, все увидеть и ощутить прелести дикой природы, не нанося ей ущерба. Значительный опыт такой работы за рубежом уже накоплен.

В мире представления о территориальной охране природы сводятся к планированию не обособленных ООПТ, а так называемых эко- логических сетей, включающих сами ООПТ и связывающие их экологические коридоры, а также другие территории с регулируемым режимом природопользования. Классические ООПТ в них становятся узловыми элементами, сохраняя наиболее ценные и уязвимые местообитания. А на прилегающих территориях и маршрутах миграции животных устанавливаются более мягкие (постоянные или сезонные) ограничения в сфере природопользования. Экологические коридоры, как правило, охватывают пути миграции диких животных. Ограничения хозяйственной деятельности здесь обычно связаны с рубками леса, распашкой земель, капитальным строительством и охотой. В некоторых странах существует специальное законодательство об экологических коридорах или об экологических сетях в целом.

Таким образом, в сложившихся в России условиях в отдельных регионах (в том числе в Иркутской области) в настоящее время ООПТ не обеспечивают надежной основы сбалансированного устойчивого управления природопользованием. Для избежания риска потери уникальных природных объектов, биоразнообразия, природных систем в целом, нарушения экологического равновесия в большинстве регионов страны необходимо совершенствование законодательной базы для ООПТ, разработка научных основ заповедного дела, направленных на охрану, рациональное использование и восстановление природных богатств, соответствующей эколого-экономической политики, реализуемой через создание, использование и развитие особо охраняемых природных территорий.

\section{СПИСОК ИСПОЛЬЗОВАННОЙ ЛИТЕРАТУРЫ}

1. Русецкая Г. Д. Устойчивое управление, экологические законы ипроблемы лесных систем / Г. Д. Русецкая // Известия Иркутской государственной экономической академии. - 2015. - Т. 25, № 3. - С. 408-415. - DOI: 10.17150/1993-3541.2015.25(3).408-415.

2. Коммонер Б. Замыкающийся круг. Природа, человек, технология / Б. Коммонер. - Л. : Гидрометеоиздат, 1974. - 280 с.

3. Основы устойчивого лесоуправления : учеб. пособие / под общ. ред. А. В. Беляковой, Н. М. ШМаткова. - 2-е изд., перераб. и доп. - М. : WWF России, 2014. - 266 с.

4. Реймерс Н. Ф. Особо охраняемые природные территории / Н. Ф. Реймерс, Ф. Р. Штильмарк. - М. : Мысль, 1978. - 295 с.

5. Реймерс Н. Ф. Охрана природы и окружающей человека среды / Н. Ф. Реймерс. - М. : Просвещение, 1992. $-320 \mathrm{c}$.

6. Анисимов А. П. Экологическое право России : учебник / А. П. Анисимов, А. Я. Рыженков, А. Е. Черноморец. - М. : Юрайт, 2010. - 504 с.

7. Иванов А. Н. Охраняемые природные территории : учеб. пособие / А. Н. Иванов, В. П. Чижова. - М. : Изд-во Моск. ун-та, 2003. - 119 с.

8. Ерофеев Б. В. Земельное право России : учебник / Б. В. Ерофеев ; под ред. Н. И. Краснова. - 9-е изд., перераб. - М. : Юрайт, 2004. - 656 с.

9. Кулешова Л. В. Основные направления и результаты научно-исследовательской работы заповедников / Л. В. Кулешова, Л. С. Исаева-Петрова // Научные исследования в заповедниках и национальных парках России. - М. : ВНИИприроды, 2001. - Вып. 2. - С. 461-470.

10. Особо охраняемые природные территории России: современное состояние и перспективы развития / сост. В. Г. Кревер, М. С. Стишов, И. А. Онуфреня. - М. : Всемир. фонд природы, 2009. - 456 с. 


\section{REFERENCES}

1. Rusetskaya G. D. Sustainable management, environmental laws and forest systems problems. Izvestiya Irkutskoi gosudarstvennoi ekonomicheskoi akademii = Izvestiya of Irkutsk State Economics Academy, 2015, vol. 25, no. 3, pp. 408-415. DOI: 10.17150/1993-3541.2015.25(3).408-415. (In Russian).

2. Kommoner B. Zamykayushchiisya krug. Priroda, chelovek, tekhnologiya [A Circle Completed. Nature, Man, Technology]. Leningrad, Gidrometeoizdat Publ., 1974. 280 p.

3. Belyakova A. V., Shmatkov N. M. (eds). Osnovy ustoichivogo lesoupravleniya [Foundations Of Sustainable Forest Management]. $2^{\text {nd }}$ ed. Moscow, WWF Russia Publ., 2014. 266 p.

4. Reimers N. F., Shtil'mark F. R. Osobo okhranyaemye prirodnye territorii [Nature Conservation Areas]. Moscow, Mysl' Publ., 1978. 295 p.

5. Reimers N. F. Okhrana prirody i okruzhayushchei cheloveka sredy [Environmental Protection]. Moscow, Prosveshchenie Publ., 1992. 320 p.

6. Anisimov A. P., Ryzhenkov A. Ya., Chernomorets A. E. Ekologicheskoe pravo Rossii [Environmental Law of Russia]. Moscow, Yurait Publ., 2010. 504 p.

7. Ivanov A. N., Chizhova V. P. Okhranyaemye prirodnye territorii [Protected Nature Areas]. Moscow, Lomonosov Moscow State University Publ., 2003. 119 p.

8. Erofeev B. V.; Krasnov N. I. (ed.). Zemel' noe pravo Rossii [Land Law of Russia]. $9^{\text {th }}$ ed. Moscow, Yurait Publ., $2004.656 \mathrm{p}$.

9. Kuleshova L. V., Isaeva-Petrova L. S. Main Aspects and Results of Scientific Activity of Nature Reserves. Nauchnye issledovaniya $v$ zapovednikakh i natsional'nykh parkakh Rossii [Scientific Research in Nature Reserves and National Parks of Russia]. Moscow, All-Russian Institute for Nature Protection Publ., 2001, iss. 2, pp. 461-470. (In Russian).

10. Krever V. G., Stishov M. S., Onufrenya I. A. (eds). Osobo okhranyaemye prirodnye territorii Rossii: sovremennoe sostoyanie i perspektivy razvitiya [Nature Conservation Areas of Russia: Current Situation and Development Prospects]. Moscow, World Wildlife Fund Publ., 2009. 456 p.

\section{Информация об авторах}

Русецкая Генриетта Денисовна - доктор технических наук, профессор, кафедра экономики и управления бизнесом, Байкальский государственный университет, 664003, г. Иркутск, ул. Ленина, 11, e-mail: rusetskaya2010@yandex.ru.

Дмытерко Елена Альбертовна - магистр, кафедра экономики и управления бизнесом, Байкальский государственный университет, 664003, г. Иркутск, ул. Ленина, 11, e-mail: dmiterko-lena@mail.ru.

\section{Для цитирования}

Русецкая Г. Д. Особо охраняемые природные территории - инструмент устойчивого управления природопользованием / Г. Д. Русецкая, Е. А. Дмытерко // Известия Байкальского государственного университета. — 2017. - Т. 27, № 4. - С. 478-487. DOI: $10.17150 / 2500-2759.2017 .27(4) .478-487$.

\section{Authors}

Genrietta D. Rusetskaya - DSc in Technical Sciences, Professor, Department of Economy and Business Administration, Baikal State University, 11 Lenin St., 664003, Irkutsk, Russian Federation, e-mail: rusetskaya2010@yandex.ru.

Elena A. Dmyterko - MSc, Department of Economy and Business Administration, Baikal State University, 11 Lenin St., 664003, Irkutsk, Russian Federation, e-mail: dmiterko-lena@mail.ru.

\section{For citation}

Rusetskaya G. D., Dmyterko E. A. Nature Conservation Areas as a Tool of Sustainable Natural Resource Management. Izvestiya Baykal'skogo gosudarstvennogo universiteta $=$ Bulletin of Baikal State University, 2017, vol. 27, no. 4, pp. 478-487. DOl: 10.17150/2500-2759.2017.27(4).478-487. (In Russian). 